\title{
Antibiotic Profile of Extended Spectrum Beta Lactamase Escherichia Coli from Clinical Samples
}

\author{
*Mahesh Kumar Chaudhary, ${ }^{1,2}$ Indrani Jadhav, ${ }^{3}$ Megha Raj Banjara, ${ }^{4}$ \\ ${ }^{1}$ Jaipur National University, Jaipur,India, ${ }^{2}$ Department of Microbiology, Nepal Mediciti Hospital, Lalitpur, \\ Nepal, ${ }^{3}$ School of Life and Basic Sciences, Jaipur National University, Jaipur,India, ${ }^{4}$ Department of \\ Microbiology, Tribhuvan University, Kirtipur, Nepal
}

*Corresponding Author: Dr. Mahesh Kumar Chaudhary; Email/Contact: mahesh_3272@yahoo.com

\begin{abstract}
Background: Extended spectrum $\beta$-lactamases have addressed the serious challenges worldwide due to the emergence of ESBL producing genes which possess a serious threat for the treatment of infections both in community and hospitals since it is found to be increasing trends of multidrug resistance. This study was focused to find out the antibiotic profile of multidrug resistant Escherichia .coli and status of ESBLs producing E.coli.

Methods: This was a cross-sectional study conducted over a period of 2 years (September 2017 to April 2019) at microbiology laboratory of Nepal Mediciti Hospital. A total of 16542 samples were processed. Various clinical samples were collected from both inpatients and outpatients aseptically and without contaminating skin commensals. Standard microbiological techniques were used for isolation and identification of pathogens. Extended spectrum beta-lactamases were phenotypically confirmed by combined disc method.
\end{abstract}

Results: Out of 1449 E.coli isolates, 323(22.29\%) were found to be MDR E.coli. Isolation rate of ESBL producing E.coli (66.56\%) were found to be high among MDR E.coli isolates.

Conclusion: There was increasing prevalence of ESBL producing E.coli and was essential to monitor antibiotic susceptibility pattern and formulate antibiotic policy to prevent the spread of MDR and ESBL producers.

Keywords: E.coli, Extended spectrum $\beta$-lactamase, Multidrug resistant

\begin{tabular}{|l|l|l|}
\hline \multicolumn{2}{|c|}{ Access this article Online } & \multicolumn{1}{c|}{ Article Info. } \\
\hline Quick Response Code & \multicolumn{1}{|c|}{ Website: } & \multicolumn{1}{c|}{ How to cite this article in Vancouver Style? } \\
\hline & www.jkahs.org.np & $\begin{array}{l}\text { Chaudhary MK, Jadhav I, Banjara MR. Antibiotic } \\
\text { Profile of Extended Beta Lactamase Escherichia Coli } \\
\text { from Clinical samples. Journal of Karnali Academy of } \\
\text { Health Sciences 2020;3(2): 102-110 }\end{array}$ \\
\cline { 2 - 3 } & $\begin{array}{l}\text { DOI: } \\
\text { https://doi.org/10.3126/ } \\
\text { jkahs.v3i2.30840 }\end{array}$ & $\begin{array}{l}\text { Accepted } \\
\text { Published Online : : : August 2020 }\end{array}$ \\
& & $\begin{array}{l}\text { Conflict of Interest : None } \\
\text { Source of Support : None }\end{array}$ \\
\hline
\end{tabular}




\section{INTRODUCTION:}

Extended-spectrum beta-lactamases (ESBLs) are the group of beta-lactamase enzymes, which hydrolyze and cause resistance to the oxyimino-cephalosporins (cefotaxime,ceftazidime, ceftriaxone, cefuroxime and cefepime) and monobactams(aztreonam), but not the cephamycins (cefoxitin and cefotetan) or carbapenems (imipenem, meropenem, and ertapenem), produced by Escherichea coli and Klebsiella pneumoniae. ${ }^{1}$

Beta-Lactam antibiotics include (penicillins, cephalosporin, carbapenems \& monobactams) are common to treat bacterial infections. The emergence of $\beta$-Lactamases mediated bacterial resistance, are due to the irrational use of antibiotics, particularly the third generation cephalosporins, which subsequently led to the development of ESBL producing bacteria. ${ }^{2}$

Emergence of resistant bacteria worldwide possess a great threat to treatment outcomes in community and hospital settings. E. coli is one of the commonest pathogen to exhibit multidrug resistance. Important risk factors for infection with MDR and ESBL Escherichia coli are prolonged antibiotic exposure, overstay in hospital, irrational use of $3^{\text {rd }}$ generation cephalosporins, severe illness, frequent use of IV devices and catheters. ${ }^{3}$

Extended spectrum beta lactamases are plasmid mediated enzymes which confer bacterial resistance to the penicillins, first, second and third generation cephalosporins and aztreonam. ${ }^{4}$

The origin of Extended spectrum beta lactamases from mutant forms of broad spectrum beta lactamases such as the TEM-1,TEM-2 and SHV1 enzymes coded by genes located on transferrable plasmids, which can easily spread form one organism to another. ${ }^{5}$ The epidemiology of ESBL-producing bacteria has been increasing day by day with crossing boundaries between hospitals and the community. The acquisition of efficient mobile elements has accelerated the transfer of various antibiotic resistance genes. Continuous surveillance system to monitor multidrug-resistant bacteria is urgently required worldwide. ${ }^{6}$ Current knowledge of prevalence of
ESBL producing strains and antibiotic status of MDR, ESBL strains will help global awareness for the formulation of antibiotic policy and antibiotic stewardship program to optimize antibiotic use for improving patient outcomes, reducing adverse consequences and provide cost-effective therapy. Therefore, the present study was conducted with an objectives of studying the antibiotic profile of MDR and ESBL Escherichia coli producing strains which helps to formulate antibiotic policy and antibiotic stewardship program for the prevention and control of infections.

\section{MATERIAL AND METHODS}

This study was a cross sectional study conducted in Microbiology Laboratory of Nepal Mediciti Hospital, Bhaisepati; Nepal from September 2017 to April 2019.This study was approved by Institutional Review Committee of Nepal Mediciti Hospital. A total of 16542 samples were processed. Various clinical samples were collected from both inpatients and outpatients aseptically and without contaminating skin commensals. Urine samples were inoculated on CLED agar whereas pus, sputum, swab ,biopsy, fluid, foley'stip, vaginal swab, catheter tip, CVP tip, BAL, suction tube, bile were inoculated aseptically on blood agar, chocolate agar and Mac-Conkey agar and incubated aerobically at $37 \pm \pm^{\circ} \mathrm{C}$ for $24-48$ hours. About $8-10 \mathrm{ml}$ of blood from adult patients and 1 $3 \mathrm{ml}$ of blood from pediatric cases were inoculated in BACTEC ${ }^{\mathrm{TM}}$ plus Aerobic/F vial and BACTEC ${ }^{\mathrm{TM}}$ PEDS PLUS/F vial respectively. The culture bottles were incubated at $37^{\circ} \mathrm{c}$ overnight (at least 5 days) inside BACTEC ${ }^{\mathrm{TM}} \mathrm{FX}$ and checked for the turbidity or any visual change daily. The specimens were sub cultured on Blood agar, chocolate agar and MacConkey agar plates and incubated aerobically at $37 \pm^{\circ} \mathrm{C}$ for 24 hours using a standard operative procedures. Significant bacterial count $\left(10^{5} \mathrm{CFU} /\right.$ $\mathrm{ml}$ ) was recorded from urine culture isolates. The identification of bacterial isolates were carried out by cultural, morphological characters, Gram stain and appropriate biochemical tests (triple sugar iron, indole, citrate, urease and motility) following standard procedures. 


\section{Antibiotic Susceptibility Tests}

Modified Kirby-Bauer disc diffusion method was applied to perform Antibiotic susceptibility test (AST) recommended by Clinical and Laboratory Standard Institute (CLSI). ${ }^{2}$ The inoculums were prepared in nutrient agar by taking 3-5 identical colonies of Escherichia coli that matched to $0.5 \mathrm{McF}$ arland standard turbidity. A sterile cotton swab was dipped into inoculum after 15 minutes and streaked over dried surface Muller Hinton agar (MHA) plate. The following commercially available antibiotic discs used for urine culture were amikacin $(30 \mu \mathrm{g})$, gentamycin $(10 \mu \mathrm{g})$, ciprofloxacin $(30 \mu \mathrm{g})$, ceftriaxone $(30 \mu \mathrm{g})$, cefotaxime $(30 \mu \mathrm{g})$, ceftazidime $(30 \mu \mathrm{g})$, nitrofurantoin $(300 \mu \mathrm{g})$, norfloxacin $(10 \mu \mathrm{g})$, nalidixic acid $(30 \mu \mathrm{g})$ and ofloxacin $(5 \mu \mathrm{g})$.For other clinical samples, antibiotic discs applied were amikacin $(30 \mu \mathrm{g})$, gentamycin $(10 \mu \mathrm{g})$, ciprofloxacin $(30 \mu \mathrm{g})$, ceftriaxone $(30 \mu \mathrm{g})$, cefotaxime $(30 \mu \mathrm{g})$, ceftazidime $(30 \mu \mathrm{g})$, cotrimoxazole $(25 \mu \mathrm{g})$, cefixime $(5 \mu \mathrm{g})$, cefepime $(30 \mu \mathrm{g})$, tigecycline $(15 \mu \mathrm{g})$, imipenem $(10 \mu \mathrm{g})$, meropenem $(10 \mu \mathrm{g})$ polymyxinb $(300 \mu \mathrm{g})$ and colistin $(10 \mu \mathrm{g})$. Plates were incubated aerobically at $37^{\circ} \mathrm{C}$ for 24 hours. Zone diameter in millimeters was measured and organisms were identified as sensitive, resistant and intermediate as per CLSI 2013 guidelines. Escherichia coli strain ATCC25922 was used as control strain.

\section{Screening of ESBL}

$3^{\text {rd }}$ generation cephalosporins (ceftazidime, cefotaxime and ceftriaxone) were used to screen ESBL producers. Isolates resistant to more than one of these agents were identified as possible ESBL producers. ${ }^{7,}{ }^{8}$ Confirmation of ESBL by confirmatory test following CLSI guidelines.

\section{Confirmatory Test for ESBL}

ESBL detection was confirmed by two phenotypic methods.

\section{Double disc synergy test (DDST)}

Microbial inoculums matched with 0.5 McFarland Standard turbidity were inoculated on dried
MHA plates. Antibiotic disc of amoxicillinclavulanate $(20 \mu \mathrm{g} / 10 \mu \mathrm{g}$ was placed at the center and ceftazidime $(30 \mu \mathrm{g})$ and cefotaxime $(30 \mu \mathrm{g})$ were placed on either side of $30 \mathrm{~mm}$ apart from center to center. Plates were incubated at $37^{\circ} \mathrm{C}$ for $18-24$ hours. Those inoculums which exhibited an enhanced zone of inhibition in between amoxicillin/clavulanic acid and ceftazidime and cefotaxime were identified as confirmed ESBL producers. ${ }^{9}, 10$

\section{Combined disc method}

Ceftazidime $(30 \mu \mathrm{g})$ alone and ceftazidime with clavulanic $\operatorname{acid}(30 \mu \mathrm{g} / 10 \mu \mathrm{g})$ and cefotaxime $(30 \mu \mathrm{g})$ and cefotaxime with clavulanic acid $(30 \mu \mathrm{g} / 10 \mu \mathrm{g})$ were placed at an appropriate distance from each other on inoculated MHA plate. The plate was incubated at $37^{\circ} \mathrm{C}$ for $18-24$ hours aerobically. Inhibition zone differences by $\geq 5 \mathrm{~mm}$ in either ceftazidime clavulanic acid with ceftazidime alone or cefotaxime clavulanic acid with cefotaxime alone was interpreted as confirmed ESBL. ${ }^{11}$ The quality control was done using Escherichia coli ATCC 25922 as negative control.

\section{Statistical Analysis}

The data was entered and percentage calculation were analyzed by using Statistical Package for Social Sciences (SPSS) version 21 software.

\section{RESULTS}

Total of 16542 samples were collected in which 1449 Escherichia coli isolates were recovered from various clinical samples of inpatients and outpatients of the hospital. The highest number of Escherichia coli was isolated from urine followed by sputum, swab,pus,blood,fluid,foley's tip,vaginal swab, catheter tip,BAL, biopsy, bile suction tube,CVP tip,ET tube. Distribution of Escherichia coli isolates on the basis of source. (Fig.1) 


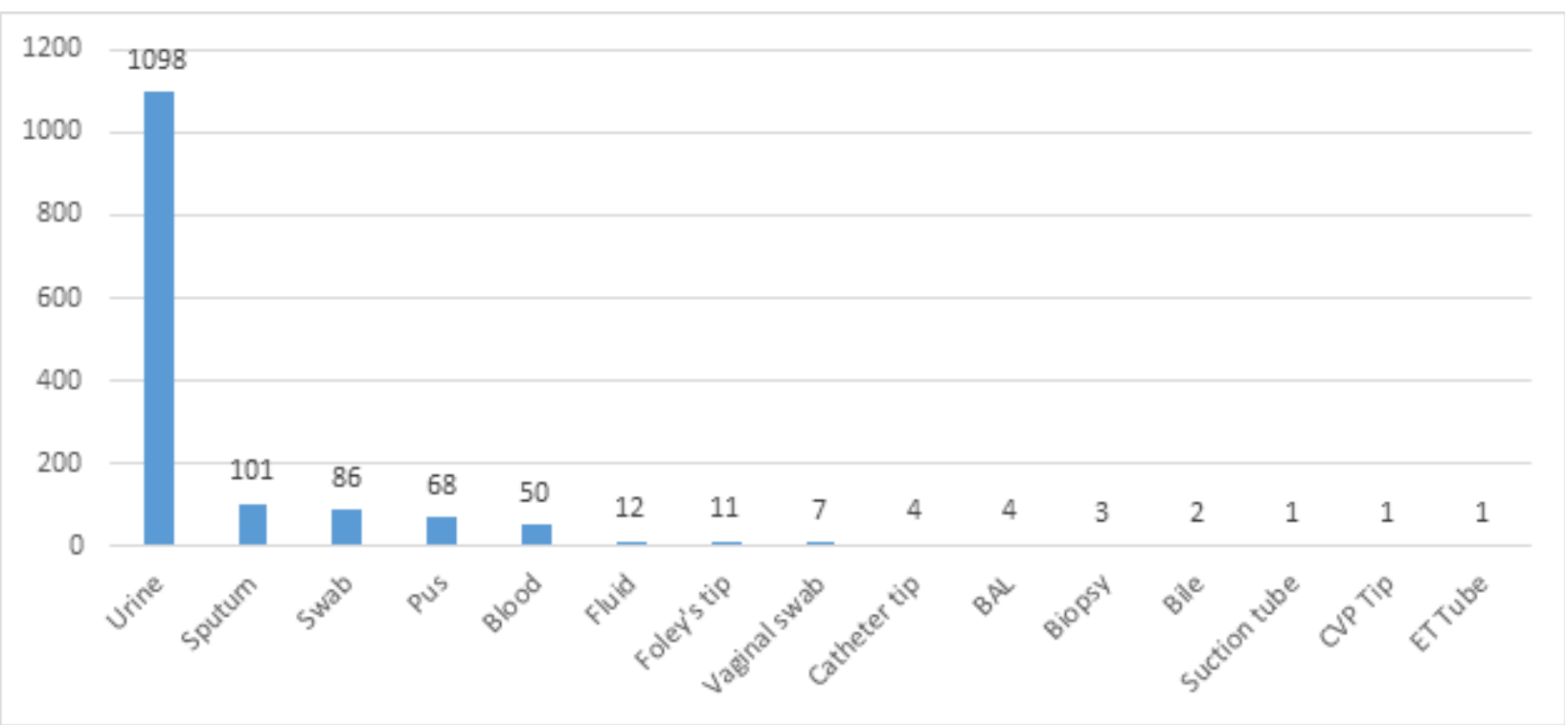

Fig.1.Source wise distribution of Escherichia coli isolates

Antimicrobial susceptibility test of Escherichia coli isolates from various clinical samples i.e. urine, sputum, swab, pus and blood were shown Table1-2. In the present study, it is observed that

Escherichia coli isolates from urine culture is $96.54 \%$ to nitrofurantoin followed by amikacin (80.78\%). Most of E.coli from urine were resistant to third generation cephalosporins indicates possible ESBL producers.

Similarly, Escherichia coli isolates from sputum, swab, pus and blood were found to be $100 \%$ sensitive to tigecycline followed by colistin and polymyxin $b$. Resistance to third

generation cephalosporins is between $26 \%$ and $93 \%$, which is highly variable. Whereas, resistant pattern of carbapenem is between $4 \%$ and $20 \%$ which is quite low. Isolates resistant to third generation cephalosporins were considered as possible ESBL producers

\section{Table 2: Antibiotic susceptibility pattern of E.coli}

\begin{tabular}{|c|c|c|c|c|c|c|c|c|}
\hline \multirow{3}{*}{ Antibiotics } & \multicolumn{2}{|l|}{ Sputum } & \multicolumn{2}{|l|}{ Swab } & \multicolumn{2}{|l|}{ Pus } & \multicolumn{2}{|l|}{ Blood } \\
\hline & \multicolumn{2}{|l|}{$\begin{array}{l}n=101 \\
\text { No }(\%)\end{array}$} & \multicolumn{2}{|l|}{$\begin{array}{l}\mathrm{n}=86 \\
\text { No }(\%)\end{array}$} & \multicolumn{2}{|l|}{$\begin{array}{l}n=68 \\
\text { No }(\%)\end{array}$} & \multicolumn{2}{|l|}{$\begin{array}{l}\mathrm{n}=50 \\
\text { No }(\%)\end{array}$} \\
\hline & Sensitive & Resistant & Sensitive & Resistant & Sensitive & Resistant & Sensitive & Resistant \\
\hline $\mathrm{AK}$ & $44(43.5)$ & $57(56.5)$ & $57(66.3)$ & $29(33.7)$ & $59(86.7)$ & $9(13.3)$ & $46(92)$ & $4(8)$ \\
\hline $\mathrm{G}$ & $42(41.5)$ & $59(58.5)$ & $61(70.9)$ & $25(29.1)$ & $57(83.8)$ & $11(16.2)$ & $41(82)$ & $9(18)$ \\
\hline CIP & $15(14.8)$ & $86(85.2)$ & $49(56.9)$ & $37(43.1)$ & $42(61.7)$ & $26(38.3)$ & $37(74)$ & $13(26)$ \\
\hline CTR & $24(23.7)$ & $77(76.3)$ & $33(38.4)$ & $53(61.6)$ & $31(45.6)$ & $37(54.4)$ & $39(78)$ & $11(22)$ \\
\hline
\end{tabular}

Table 1: Antibiotic susceptibility pattern of $E$.coli from urine

\begin{tabular}{|ll|l|}
\hline Antibiotics & \multicolumn{1}{c|}{$\begin{array}{l}\text { Antibiotic } \\
\text { rate No (\%) E.coli(1098) }\end{array}$} \\
\cline { 2 - 3 } & Sensitive & Resistant \\
\hline Amikacin(AK) & $887(80.7)$ & $211(19.3)$ \\
\hline Gentamycin(G) & $812(73.9)$ & $286(26.1)$ \\
\hline Ciprofloxacin(CIP) & $511(46.5)$ & $587(53.5)$ \\
\hline Ceftriaxone(CTR) & $646(58.8)$ & $452(41.2)$ \\
\hline Cefotaxime(CTX) & $646(58.8)$ & $452(41.2)$ \\
\hline Ceftazidime(CAZ) & $646(58.8)$ & $452(41.2)$ \\
\hline Nitrofurantoin(NIT) & $1060(96.5)$ & $38(3.5)$ \\
\hline Norfloxacin(NX) & $498(45.4)$ & $600(54.6)$ \\
\hline Nalidixic acid(NA) & $258(23.5)$ & $840(76.5)$ \\
\hline Ofloxacin(OF) & $493(44.8)$ & $605(55.2)$ \\
\hline Co-trimoxazole(COT) & $586(53.4)$ & $512(46.6)$ \\
\hline
\end{tabular}




\begin{tabular}{|l|l|l|l|l|l|l|l|l|}
\hline CTX & $15(14.8)$ & $86(85.2)$ & $49(56.9)$ & $37(73.1)$ & $41(60.3)$ & $27(39.7)$ & $37(74)$ & $13(26)$ \\
\hline CAZ & $24(23.7)$ & $77(76.3)$ & $61(70.9)$ & $25(29.1)$ & $31(45.6)$ & $37(54.4)$ & $39(78)$ & $11(22)$ \\
\hline COT & $23(22.7)$ & $78(77.3)$ & $43(50)$ & $43(50)$ & $35(51.4)$ & $33(48.6)$ & $34(68)$ & $16(32)$ \\
\hline CFX & $7(6.9)$ & $94(93.1)$ & $61(70.9)$ & $25(29.1)$ & $48(70.5)$ & $20(29.5)$ & $32(64)$ & $18(36)$ \\
\hline CPM & $11(10.8)$ & $90(89.2)$ & $61(70.9)$ & $25(29.1)$ & $48(70.5)$ & $20(29.5)$ & $39(78)$ & $11(22)$ \\
\hline TGC & $101(100)$ & - & $86(100)$ & - & $68(100)$ & - & $50(100)$ & - \\
\hline IPM & $86(85.2)$ & $15(14.8)$ & $68(79.1)$ & $18(20.9)$ & $59(86.7)$ & $9(13.3)$ & $45(90)$ & $5(10)$ \\
\hline MRP & $94(93.1)$ & $7(6.9)$ & $81(94.2)$ & $5(5.8)$ & $62(91.2)$ & $6(8.8)$ & $48(96)$ & $2(4)$ \\
\hline PB & $100(99.2)$ & $1(0.8)$ & $85(98.8)$ & $1(1.2)$ & $66(97.1)$ & $2(2.9)$ & $50(100)$ & - \\
\hline CL & $101(100)$ & - & $85(98.8)$ & $1(1.2)$ & $67(98.5)$ & $1(1.5)$ & $50(100)$ & - \\
\hline C* & - & - & - & - & - & - & $45(90)$ & $5(10)$ \\
\hline
\end{tabular}

Note: AK-Amikacin, G-Gentamycin, CIP-Ciprofloxacin, CTX-Ceftazidime,CAZ-Ceftazidime,COTCotrimoxazole CFX-Cefixime, CPM-Cefepime, TGC-Tigecycline, IPM-Imipenem, MRP-Meropenem, PBPolymyxin b, CL-Colistin

Note: * C-Chloramphenicol used in blood culture

Of the 1449 total E.coli isolates, 323/1449(22.29\%) isolates were multi -drug resistance.Out of the total MDR Escherichia coli isolates, 215/323(66.56\%) isolates were ESBL producers by combined disc method. However, maximum number of ESBL production was shown by using ceftazidime/ ceftazidime: clavulanic acid (CAZ/CAZC) combination. The maximum number of ESBL Escherichiacoli was isolated from urine 194(90.23\%), followed by sputum $12(5.58 \%)$, swab5 (2.32\%), pus $2(0.93 \%)$ and blood $2(0.93 \%)$ as shown in table 3 .

Antibiotic susceptibility pattern of ESBL E.coli producers showed similar pattern of sensitivity to tigecycline (100\%) followed by polymyxin $b$, colistin and meropenem as non-ESBL producing E.coli. But the resistant to third generation cephalosporins showed increasing trends as compared to non-ESBL producers (table 4).

Table 3: Distribution of MDR and ESBL E.coli from clinical samples

\begin{tabular}{|l|l|l|}
\hline Specimen & MDR E. coli No. (\%) & ESBL E.coli No (\%) \\
\hline Urine & $255(78.95)$ & $194(90.23 \%)$ \\
\hline Sputum & $46(14.24)$ & $12(5.58 \%)$ \\
\hline Swab & $13(4.1)$ & $5(2.32 \%)$ \\
\hline Pus & $5(1.54)$ & $2(0.93 \%)$ \\
\hline Blood & $4(1.24)$ & $2(0.93 \%)$ \\
\hline Total & $323(100.0)$ & $215(100.0)$ \\
\hline
\end{tabular}

Table 4: Antibiotic susceptibility pattern of ESBL E.coli

\begin{tabular}{|l|l|l|} 
Antibiotics & \multicolumn{2}{c|}{$\begin{array}{c}\text { Antibiotic susceptibility } \\
\text { rate No (\%) ESBL } \\
\text { E.coli(215) }\end{array}$} \\
\cline { 2 - 3 } & Sensitive & Resistant \\
\hline Amikacin(AK) & $197(91.6)$ & $18(8.4)$ \\
\hline Gentamycin(G) & $180(83.7)$ & $35(16.3)$ \\
\hline Ciprofloxacin(CIP) & $125(58.2)$ & $90(41.8)$ \\
\hline Ceftriaxone(CTR) & - & $215(100)$ \\
\hline Cefotaxime(CTX) & 1 & $214(97.3)$ \\
\hline Ceftazidime(CAZ) & - & $215(100)$ \\
\hline Nitrofurantion(NIT)* & $182(93.8)$ & $12(6.2)$ \\
\hline Norfloxacin(NX)* & $109(56.2)$ & $85(43.8)$ \\
\hline Nalidixic acid(NA)* & $9(4.6)$ & $185(95.4)$ \\
\hline Ofloxacin(OF)* & $91(46.9)$ & $103(53.1)$ \\
\hline Tigecycline(TGC) & $215(100)$ & - \\
\hline Imipenem(IPM) & $148(68.8)$ & $67(31.2)$ \\
\hline Meropenem(MRP) & $194(90.2)$ & $21(9.8)$ \\
\hline Polymyxin B(PB) & $215(100)$ & - \\
\hline Colistin(CL) & $215(100)$ & - \\
\hline
\end{tabular}

Note: * used in urine culture

\section{DISCUSSION}

Despite the discovery of antibiotics, emergence of MDR and ESBLs producing bacteria due to the extensive use of extended spectrum cephalosporins (ESCs) since early 1980's is a significant evolution 
in antimicrobial resistance. Several other factors including misuse of drugs, inappropriate antibiotic treatment, extensive use of antimicrobials has also contributed to the emergence of drug resistant bacteria. The present study was conducted in the department of microbiology laboratory, Nepal Mediciti Hospital during a period of September 2017 to April 2019 with the aim of understanding the antibiotic profile of MDR and ESBL producing Escherichia coli.

The present study documented that the highest number of E.coli isolates were recovered from urine $(n=1098(75.77)$. With regard to urinary tract infection, E.coli showed great extent of resistance to nalidixic acid, co-trimoxazole and third generation cephalosporins. Similar pattern of resistant in urinary isolates of E.coli was shown in Nepal and India. ${ }^{12,13,14 .}$ In contrast to our result, Perez et.al reported E.coli isolates were $94 \%$ resistant to ceftriaxone ${ }^{15}$ This may be due to the irrational use of third generation cephalosporins ${ }^{16}$ However; a significant degree of susceptibility was found to nitrofurantoin (96.5\%) followed by amikacin (80.7\%) and gentamycin (73.9\%).Similar findings have been reported in various studies. ${ }^{12,13,14,17,11,18}$. This may be due to the rational use of these drugs in UTIs cases since it is reserved drug for UTIs.

In this study, analysis of antibiotic susceptibility of E.coli isolated from sputum, blood, swab, pus demonstrated a significant degree of susceptibility towards tigecycline $(100 \%)$ followed by colistin ( $98 \%$ to $100 \%)$, polymyxinb ( $97 \%$ to $100 \%)$, meropenem ( $91 \%$ to $96 \%$ ) and imipenem ( $79 \%$ to $90 \%)$.Similar results were shown in other studies ${ }^{14,19}$. It was found to be higher resistant pattern of cephalosporins $(22 \%$ to $93 \%)$, fluoroquinolones ( $26 \%$ to $85 \%$ ), aminoglycosides $(8 \%$ to $59 \%)$ as compared to urine isolates. Several studies conducted in Nepal showed similar results. ${ }^{12,19,20}$ In contrast to our study, Bamford et al.noted higher susceptibility pattern towards cephalosporins, fluoroquinolones, aminoglycosides..$^{21}$ The increased level of drug resistance is a major concern worldwide since these are the first line drugs recommended internationally ${ }^{22,23}$ and are irrational used in public and private sectors. ${ }^{24,25}$.
The present study noted (323/1449)22.29\% MDR E.coli isolates that were suspected of being ESBL producers were confirmed by combined disc method. Prevalence of ESBL E.coli was (215/323)66.56\% which was alarming high. Several studies reported high prevalence i.e.40-70\% of ESBL E.coli among MDR E.coli. ${ }^{11,19,26-29}$ Kashyap et.al reported 37\% ESBLE.coli. ${ }^{30}$ But the study conducted by Anil chander et.al in 2013 observed only 13.51\% ESBL prevalence in E.coli which is analogous result to other study. ${ }^{31,32}$. This is not similar with our study due to the variation in geography, study design and selection of type of antimicrobial agents. The indiscriminate use of beta-lactam antibiotics leads to the generation of selective pressures which have led to the selection of a variety of mutated forms of beta lactamases. ${ }^{33}$.Antibiotic profile of ESBL producing E.coli were found to be higher sensitivity towards tigecycline (100\%), polymyxin B (100\%), colistin $(100 \%)$ followed by amikacin $(91.6 \%)$, meropenem (90.2\%) and imipenem (68.8\%).Susceptibility to nitrofurantoin was $93.8 \%$ against ESBL producing E.coli isolated form urine. So, it is the drug of choice for treating infection caused by ESBL producing E.coli. The result of similar study conducted in Nepal and India. ${ }^{34,}$ 14, 8 .High resistant rates were observed to cephalosporins, nalidixic acid followed by fluoroquinolones. Similar findings were reported by Al-Zarouni et al. ${ }^{35}$

\section{CONCLUSION}

High prevalence of extended spectrum beta lactamase (ESBL) E.coli was observed. No resistance was documented to tigecycline, polymyxin $b$, and colistin suggesting the suitable drug of choice for treating ESBL producing E.coli causing life threatening infections. Of particular concern, proper formulation of antibiotic policy and antibiotic stewardship program absolutely required in each and every health sectors by all concern authorities. This study forwarded a real massage to all the clinicians for the emergence of XDR and PDR resistant bacteria in near future, if past experience with MDR and ESBLs was any indicator. 
Acknowledgement: We would like to acknowledge Nepal Mediciti Hospital, Nepal for providing ethical approval and research work. We also thank to the microbiology laboratory staffs for their valuable support to complete this work.

\section{REFERENCES}

1. Lal P, Kapil A, Das BK and Sood S.Occurrence of TEM and SHV gene in extended spectrum beta lactamases (ESBLs) producing Klebsiella spp. isolated from a tertiary care hospital. Indian Journal Medica.2007; 125: 173-178. https:// pubmed.ncbi.nlm.nih.gov/17431288/

2. CLSI. Performance Standards for Antimicrobial Susceptibility Testing, Twenty-Third Informational Supplement, CLSI Document M100-S23, Wayne, PA: Clinical and Laboratory Standards Institute, 2013.

3. Chaudhary U, Aggarwal R. Extended spectrum $\beta$-lactamases (ESBL): Emerging threat to clinical therapeutics. Indian $\mathrm{J}$ Med Microbiol.2004;22(2):75-80 https://pubmed. ncbi.nlm.nih.gov/17642700/

4. Johann DD, Pitout DK, Kevin BL.Extended spectrum beta lactamases producing Enterobacteriaceae: an emerging public health concern. Lancet InfectDis.2008; 8:159-66. https://doi.org/10.1016/S1473-3099(08)700410

5. YahayaMD, GaladimaBG,SamboBZ,AaronOA. Characterization of Extended spectrum beta lactamase from Escherichia coli and Klebsiella species from North Eastern Nigeria. Journal of Clinical and Diagnostic Research.2016;10(2):7-10 DOI: $10.7860 / \mathrm{JCDR} / 2016 / 16330.7254$ PMCID: $\underline{\text { PMC4800525 }}$

6. Fluit AC and Schmitz FJ. Class 1 Integrons, Gene Cassettes, Mobility, and Epidemiology. Eur J ClinMicrobiol Infect Dis. 1999;18(11):76170. https://doi.org/10.1007/s100960050398 PMid:10614949

7. Coudron PE,Moland
CC.Occurrence and detection of extended spectrum beta-lactamases in members of the family Enterobacteriaceae at a veterans medical center: seek and you may find.J.Clin Microbial.1997;35(10):2593-97. https://doi. org/10.1128/JCM.35.10.2593-2597.1997 PMid:9316913

8. Babypadmini S,Appalaraju B.Extended spectrum beta-lactamases in urinary isolates of Escherichia coli and Klebsiella pneumoniae prevalence and susceptibility pattern in a tertiary care hospital.Indian $\mathrm{J}$ Med Microbiol.2004;22(3):172-174

9. Drieux L,Brossier F,Sougakoff W,Jarlier V.Phenotypic detection of extended spectrum $\beta$-lactamases production in Enterobacteriaceae: Review and bench guide.Clin.Microbiol. Infect. $2008 ; 14(1): 90-103 . h t t p s: / / d o i$. org/10.1111/j.1469-0691.2007.01846.x PMid:18154532

10. Clinical Laboratory Standard Institute. Performance standards for antimicrobial susceptibility testing; twenty-second informational supplement. Clinical Laboratory Standard Institute. Wayne, Pennsylvania, USA.2012;32:70-71.

11. Thakur S,Pokhrel N,Sharma M.Prevalence of multidrug resistant enterobacteriaceae and extended spectrum beta-lactamase producing E.coli in urinary tract infection. Research Journal of Pharmaceutical, Biological and Chemical Sciences.2013;4:1615-1621.

12. Subedi S,Chaudhary M,Shrestha B.High MDR AND ESBL Producing Escherichia coli and Klebsiella pneumoniae from Urine,Pus and Sputum Samples. British Journal of Medicine \& Medical Research.2016;13(10):1-10. https:// doi.org/10.9734/BJMMR/2016/23350

13. Rimal U,Thapa S,Maharjan R.Prevalence of Extended Spectrum Beta-Lactamase Producing Escherichia coli and Klebsiella species from Urinary Specimens of Children attending Friendship International Children's Hospital. Nepal Journal of Biotechnology. 2017;5(1):32-38. https://doi.org/10.3126/njb.v5i1.18868 
14. Kumar D, Singh AK, Ali R, Chander Y.Antimicrobial Susceptibility Profile of Extended Spectrum $\beta$-Lactamase (ESBL) Producing Escherichia coli from Various Clinical Samples. Infect Dis.2014;7:1-8. https://doi.org/10.4137/IDRT.S 13820 PMid:24847178 PMCid:PMC4024053

15. Perez F,Endimiani A,Hujer KM,Bonomo RA.The continuing challenge of ESBLs. CurrOpin Pharmacol.2007; 7:459-469. https://doi.org/10.1016/j.coph.2007.08.003 PMid:17875405 PMCid:PMC2235939

16. Shobha KL,Gowrish RS,Sugandhi R,Sreeja CK.Prevalence of extended spectrum beta lactamases in urinary isolates of Escherichia,Klebsiella and Citrobacter species and their antimicrobial susceptibility pattern in tertiary care hospital.Ind J Pract Doct.2007;3:12.

16. Shobha KL,Gowrish RS,Sugandhi R,Sreeja CK.Prevalence of extended spectrum beta lactamases in urinary isolates of Escherichia,Klebsiella and Citrobacter species and their antimicrobial susceptibility pattern in tertiary care hospital.Ind J Pract Doct.2007;3:12.

17. Chander A,Shrestha C.Prevalence of extended spectrum beta lactamase producing Escherichai coli and Klebsiella pneumoniae urinary isolates in a tertiary care hospital in Kathmandu, Nepal. BMC Research Notes.2013; 6:487. https://doi. org/10.1186/1756-0500-6-487 PMid:24274894 PMCid:PMC4222089

18. Chaudhari KB,Singh KG,Parajuli PK,Shrestha K.Incidence and susceptibility of uropathogens isolatedamong the patientsattertiary carehospital inEastern Nepal.JNobelMedColl.2016;5:51-55. https://doi.org/10.3126/jonmc.v5i2.16318

19. Shrestha B,Shrestha S,Mishra SK,Kattel HP,Tada T,Ohara $\mathrm{H}$, et al.Phenotypic Characterization of Multidrug-resistant Escherichia coli with Special Reference to Extended-spectrum-beta-lactamases and Metallo-beta-lactamases in a Tertiary Care
Center.J Nepal Med Assoc.2015;53(198):89-95. https://doi.org/10.31729/jnma.2768

20. YadavK,PrakashS.ScreeningofESBLProducing Multidrug Resistant E.coli from Urinary Tract Infection Suspected Cases in Southern Terai of Nepal.J Infect Dis Diagn.2017;2:2 https://doi.org/10.4172/2576-389X.1000116

21. Bamford C,Bonorchis K,Ryan A,Hoffmann R,Naicker P,Maloba $M$, et al.Antimicrobial susceptibility patterns of Escherichia coli strains isolated from urine samples in South Africa from 2007-2011.South Afr J Epidemiol Infect.2012;27(2):46-52. https://doi.org/10.108 0/10158782.2012.11441483

22. Gupta K, Hooton TM, Naber KG,Wullt B, Colgan R, Miller LG, et al.International clinical practice guidelines for the treatment of acute uncomplicated cystitis and pyelonephritis in women: A 2010 update by the Infectious Diseases Society of America and the European Society for Microbiology and Infectious Diseases.Clin Infect Dis.2011;52:e103-e120. https://doi.org/10.1093/cid/ciq2 57 PMid:21292654

23. Hooton TM,Scholes D,Gupta K,Stapleton AE,Roberts PL,Stamm WE.Amoxicillinclavulanate vs ciprofloxacin for the treatment of uncomplicated cystitis in women:a randomized trial.JAMA,2005;293:949-955. https://doi. org/10.1001/jama.293.8.949 PMid:15728165

24. Bosch F,vanVuuren C,Joubert G.Antimicrobial resistance patterns in outpatient urinary tract infections: the constant need to revise prescribing habits.S Afr Med J.2011;101(5):328-331. https://doi.org/10.7196/S A M J.4346 PMid:21837876

25. Gumede L,Van der Hoven L,Maseko V,De Kock E,Smuts F,Perovic O,et al.Antimicrobial susceptibility profiles for community-acquired urinary tract pathogens in Gauteng province.Durban:Southern African Journal of Epidemiology and Infection.2011;26(3):122-154. https://doi.org/1 $\underline{0.1080 / 10158782.2011 .11441438}$ 
26. Kulkarni DM,Bardapurkar SA,Nilekar SL,More SR.Prevalence of extended spectrum $\beta$-lactamase (ESBL) producing E.coli and Klebsiella species in urinary isolates.IOSR J Dent Med Sci.2016;15:26-29.

27. Sharma S,Bhat GK.Virulence factors and drug resistance in Escherichia coli isolated from extraintestinal infection. Ind J Med Microbiol.2007; 25:369-373. https://doi.org/10.4103/0255-0857.37341 PMid:18087087

28. Goyal A,Prasad KN,Prasad A,Gupta S,Ghosal U,Ayyagari A.Extended-spectrum $\beta$-lactamases in Escherichia coli and Klebsiella pneumoniae and associated risk factors.Indian $\mathrm{J}$ Med Res.2009;129:695-700. $\quad$ https://pubmed.ncbi. nlm.nih.gov/19692752/

29. Rajan S, Prabavathy J. Antibiotic Sensitivity and Phenotypic Detection Of ESBL producing E.Coli Strains Causing Urinary Tract Infection In a Community Hospital, Chennai, Tamil Nadu, India. WebmedCentral Pharmaceutical Sciences 2012;3(11):WMC003840

30. Kashyap G,Gupta S,Mamoria PV,Durlabhji P,Jain D.Increasing prevalence of extended spectrum beta lactamases (ESBLs) producing E.coli and Klebsiella spp in outpatient departments (OPDs) patients in urinary tract infections (UTIs) in tertiary care hospital.Int $\mathrm{J}$ Curr Res Rev.2013;5:87-93. http://ijcrr.com/ article html.php?did=1323

32. Shafiq M,Rahman H,Qasim M,Ayub $\mathrm{N}$,Hussain S,Khan J,et al.Prevalence of plasmid-mediated ampC $\beta$-lactamases in Escherichia coli and Klebsiella pneumoniae at tertiary care hospital of Islamabad,Pakistan. Euro J Microbiol Immunol.2013;4:267-271. https://doi.org/10.1556/EuJMI.3.2013.4.5 PMid:24294496 PMCid:PMC3838542
33. N,Hussain S,Khan J,et al.Prevalence of plasmid-mediated ampC $\beta$-lactamases in Escherichia coli and Klebsiella pneumoniae at tertiary care hospital of Islamabad,Pakistan. Euro J Microbiol Immunol.2013;4:267-271. https://doi.org/10.1556/EuJMI.3.2013.4.5 PMid:24294496 PMCid:PMC3838542

34. Owens RC Jrl,Rice L.Hospital based strategies for combating resistance.Clinical Infectious Disease.2006;42:S173-81.

35. Khanal S,Joshi DR,Bhatta DR,Devkota U,Pokhrel BM.Beta-lactamase-producing multidrug-resistant bacterial pathogens from tracheal aspirates of intensive care unit patients at National Institute of Neurological and Allied Sciences,Nepal.ISRN Microbiology.2013:5.

36. Al-Zarouni M,Senok A,Rashid F,AlJesmi SM,Panigrahi D.Prevalence and antimicrobial susceptibility pattern of extended-spectrum beta-lactamase producing Enterobacteriaceae in the United Arab Emirates.Med Princ and Prac.2008;17(1):3236.https://doi.org/10.1159/000109587 PMid:18059098 